This is a draft of a chapter that has been accepted for publication by De Gruyter in the book "Griechische Literaturgeschichtsschreibung. Traditionen, Probleme und Konzepte” edited by J. Grethlein and A. Rengakos published in 2017. https://www.degruyter.com/view/product/469502

The research for this chapter has received funding from the European Research Council under the European Union's Seventh Framework Programme (FP/2007-2013)/ERC Grant Agreement no. 312321 (AncNar).

\title{
Literary History! The Case of Ancient Greek Literature
}

\section{Literary History Challenged}

Modern literary history emerged as part of Historicism. The acute awareness of the historical nature of human culture led to a strong interest in the development of literature, often of national literatures. The history of literature was envisaged as an organic process, as the expression of a people's evolution. ${ }^{1}$ However, just as the tenets of Historicism lost their lustre, the idea of literary history started to draw fire. The critique can be traced back to the 19th century, but it gained force in the 20th century, so much force indeed that literature itself was declared "die Unmöglichkeitserklärung der Literaturgeschichtsschreibung“². Nobody less prominent than René Wellek stated gloomily: "There is no progress, no development, no history of art except a history of writers, institutions and techniques. This is, at least for me, the end of an illusion, the fall of literary history." ${ }^{3}$

One point that has been voiced by scholars from a wide range of proveniences is the idea that a historical approach is incapable of capturing the essence of literature. Wellek and Warren claimed: "Most leading histories of literature are either histories of civilization or collections of critical essays. One type is not a history of art; the other, not a history of art."4 Before them, Croce had asserted "che la vera forma logica della storiografia letterarioartistica è la caratteristica del singolo artista e dell' opera sua". 5 The appropriate means of criticism are thus articles and monographs, but not literary histories. In Germany, Emil Staiger's rejection of literary history was particularly influential. As Staiger states in the introduction to Die Zeit als Einbildungskraft des Dichters, works of art cannot be explained; they are merely objects of interpretation. More recently and from a yet different angle, HansUlrich Gumbrecht foregrounds the "literary event", the reader's "punctual feeling of being inscribed into the (not) only material world". ${ }^{6}$ Literary texts transcend history; their aim is to

\footnotetext{
${ }^{1}$ Cf. Wellek (1956) on the role of Classical studies in the emergence of literary history, see Most (2008). For the understanding of Historicism as a broad cultural phenomenon not confined to the academic discipline of history, see Oexle (1996).

${ }^{2}$ Hamacher (1986) 15. For surveys of the critique of literary history, see Wellek (1973) 427-40; Buschmeier (2014) 17-29.

${ }^{3}$ Wellek (1973) 440.

${ }^{4}$ Wellek/Warren (1949) 264.

${ }^{5}$ Croce (1918) 11.

${ }^{6}$ Gumbrecht (2008) 530.
} 
evoke a presence in which the reader can immerse himself. There is little, if anything, that literary history can contribute to such an understanding of texts.

While this line of criticism is based on a concept of art as transhistorical, poststructuralism took issue with other aspects. ${ }^{7}$ The idea of continuity on which traditional literary histories are premised sat uncomfortably with the eagerness to identify ruptures and fissures. The teleological constructions in particular that form the backbone of many traditional literary histories were a red flag for post-structuralists. In general the narrative form of literary history attracted the critcism of an intellectual tradition that questioned the representational capacity of narrative and nurtured an aversion to grands récits. After the Russian formalists and their structuralist heirs had confined their analysis of literary developments to purely literary innovations, post-structuralism challenged the very idea of development.

This and other lines of attack paved the way for alternative forms of alternative literary histories, notably the so-called encyclopedic literary histories. It is not the claim for comprehensiveness that justifies the label "encyclopedic" here, but the compilation of entries, composed by a multitude of scholars, that do not add up to a unified narrative. As the editors of the 1987 Columbia Literary History of the United States write in the introduction, "in contrast to the 1984 volume, we have made no attempt to tell a 'single, unified story' with a 'coherent narrative'... No longer is it possible, or desirable, to formulate an image of continuity." "A New History of French Literature, published two years later, is even more radical. Its articles forego the surveys one would expect and instead offer highly specialized treatments. There is for example an essay that relates Proust's theory of art to his consciousness of death, but general information about his work and life is missing: "A reader who acquired his information only from A New History of French Literature would not know why Proust is a topic at all."9

In the introduction to A History of German Literature, David Wellbery invokes Celan's "Jedes Gedicht ist datierbar" and claims "a radicalization of the idea that literature is historical". ${ }^{10}$ The entries focus on dates, often specific days, which are mostly linked to minor events that, however, are supposed to shed light on an author and his work. The choice of dates and the chronological ordering of entries aim not so much at contextualizing literary texts as at saving the "encounter" of the reader with the text. Wellbery flags his debt to Walter

\footnotetext{
${ }^{7}$ E.g. de Man (1971); Hamacher (1986).

${ }^{8}$ Elliott (1987) xxi.

${ }^{9}$ Perkins (1992) 58.

${ }^{10}$ Wellbery (2004) xvii.
} 
Benjamin's non-linear understanding of history without caring to give a specific reference (is this, I wonder, the de rigueur way of quoting Benjamin?), but Benjamin's conclusion in his essay on Literaturgeschichte und Literaturwissenschaft illustrates the spirit: "Denn es handelt sich ja nicht darum, die Werke des Schrifttums im Zusammenhang ihrer Zeit darzustellen, sondern in der Zeit, da sie entstanden, die Zeit, die sie erkennt - das ist die unsere - zur Darstellung zu bringen. Damit wird die Literatur ein Organon der Geschichte und sie dazu nicht das Schrifttum - zum Stoffgebiet der Historie zu machen, ist die Aufgabe der Literaturgeschichte." ${ }^{11}$ Wellbery’s literary history relies on what is considered a direct communion between the act of reading and the moment in which the work was written.

Even who regards the encyclopedic histories of literature as experimental may be ready to see that their discomfort with traditional approaches resonates widely. It can be sensed not least, I suggest, in the current flood of Companions. Most major academic presses eagerly churn out Companions on individual authors, genres and epochs. Who, for example, wishes to inform himself about Herodotus, can rely on a Brill's and Cambridge Companion to Herodotus as well as the more general Companion to Greek and Roman Historiography. ${ }^{12} \mathrm{~A}$ Cambridge Companion on Thucydides and an Oxford Handbook of Thucydides are simultaneously in preparation to complement the Brill's Companion to Thucydides. ${ }^{13}$ There are also histories of classical historiography, but they are clearly less popular. ${ }^{14}$ Companions may have their roots more in the specialization of scholarship than in theoretical reflection, but their format chimes in with the scepticism about historical development. At least, most readers seem to prefer a thematic engagement with an author over his assessment in the history of literature. Even the Handbuch der griechischen Literatur der Antike, launched as "eine neue große Literaturgeschichte im Handbuch der Altertumswissenschaften" 15 emphasizes the synchronic aspect. The discussions of the individual epochs are by and large unconnected, often even assigned to different authors. The two volumes published so far are more invested in detailed information about individual authors than in drawing lines of development.

It thus seems that the form of encyclopedic histories of literature reflects a broader hesitance about diachronic accounts. However, the attempt to conceive literary histories in light of the post-structuralist and "presentist" critique comes at a considerable price which has

\footnotetext{
${ }^{11}$ Benjamin (1991 [1912-1930]) 290. It is curious that Jauß (1970) 170 n. 63 quotes this passage as corroborating his Rezeptionsästhetik which, in its Gadamerian approach, is a far cry from Benjamin's epiphanic link between past and present.

${ }^{12}$ Bakker (2002); Dewald (2006); Marincola (2011).

${ }^{13}$ Rengakos (2006).

${ }^{14}$ Notably, introductions such as Pitcher (2009) opt for a thematic structure.

${ }^{15}$ Zimmermann (2011) vi.
} 
been spelt out mercilessly by Perkins: "Encyclopedic form is intellectually deficient. Its explanations of past happenings are piecemeal, may be inconsistent with each other, and are admitted to be inadequate. It precludes a vision of its subject. Because it aspires to reflect the past in its multiplicity and heterogeneity, it does not organize the past, in this sense, it is not history. There is little excitement in reading it." ${ }^{~}$ Many readers will disagree about the pleasure of browsing, say, A History of German Literature, but it is undeniable that, while offering many glimpses, it does not provide the kind of view that is expected from a history. The reader himself has to establish the links between individual works and authors. The faithfulness to the postmodern farewell to history abandons the diachronic dimension.

There is something parasitical to post-structuralism which renders its reflections, as scintillating as they often are, ultimately unsatifactory. Post-structuralism presupposes, even depends on systems and concepts that can be subjected to deconstruction. The triumphant gesture of deconstruction belies that it has little power in and of itself. In the case of encyclopedic literay histories, it has been noted that they require an informed reader who is familiar with the canonization and periodisation under deconstruction. ${ }^{17}$ I think the intellectual dishonesty at play is graver. The debt of encyclopedic literary histories to traditional works goes beyond using their narratives as fodder for the blind shredder of deconstruction. The dates chosen in A New History of German Literature may appear iconoclastic in their randomness, but the works chosen conform to the canon established by conventional literary histories. Certainly, Max und Moritz are discussed in the same format as Nibelungenlied and Faust, and yet, the selection of works follows the disciplinary tradition. ${ }^{18}$ Encyclopedic histories of literature reject the assumption of development but simultaneously adopt the choice of texts made with the help of the notion of development.

The case of Tim Whitmarsh's Ancient Greek Literature is even more conspicuous. Whitmarsh announces that he has "avoided any grand narratives about rises and falls, ebbs and flows". Instead he has written "an anti-narrative book in the post-modern tradition: a work of fragments, a series of discrete visits to independent sites of literary production". ${ }^{19}$ However, as Whitmarsh himself admits, he concentrates on works of the classical canon, ignoring for example Christian and Jewish authors as well as such marginal texts as magic spells. More disconcertingly, the structure of Whitmarsh's book is predicated on the mainstream accounts of literary history. As Martin Hose observes, the structure of Ancient

\footnotetext{
${ }^{16}$ Perkins (1992) 60.

${ }^{17}$ Perkins (1992) 172; Müller (2014) 172.

${ }^{18}$ Cf. Müller (2014) 174.

${ }^{19}$ Whitmarsh (2004) 16.
} 
Greek Literature reproduces the epochs of traditional literary history, Archaic, Classical, Hellenistic and Imperial; it even seems to subscribe to the teleological sequence of epic, lyric and drama championed by Geistesgeschichte. ${ }^{20}$ Here as in other cases, an alternative history of literature clandestinely relies on structures of its traditional counterparts whose rejection is trumpeted as its raison d'être.

We can observe here something like the return of the repressed, to invoke a darling trope of postmodern thought. The hidden debts of anti-Historicist literary histories to their traditional predecessors ironically highlight the impact of history. The power of history is felt not only in scholarship, but also in literature (if we define it narrowly to exclude scholarly works). In fact, literature is historical. This may sound like a truism, but it is crucial for the assessment of literature and, given the vogue of ahistorical concepts, bears emphasizing. Even those in defence of literary history have claimed that, while practically indispensable, it is theoretically impossible: "My opinion is, then, that we cannot write literary history with intellectual conviction but we must read it." ${ }^{21}$ However, literary histories are not only a practical requirement for undergraduate classes and examinations; the historical nature of literature makes a historical approach theoretically indispensable if we want to do justice to the essence of literature. Already present in studies that view individual texts against the backdrop of earlier or later works, the historical dimension of literature is fully grasped in literary histories.

\section{Reconsidering Literary History in the Light of Ancient Greek History}

The most prominent attempt to conceptualize the entwinement of literature with history is arguably Jauß' Rezeptionsästhetik, programmatically presented in his Konstanz inaugural lecture Literaturgeschichte als Provokation. ${ }^{22}$ Jauß couches his recuperation of history in a critique of Marxist and formalist approaches. Whereas the Marxist Widerspiegelungsästhetik inexcusably simplifies the complex interaction between history and literature, the formalists unnecessarily confine the development of literature to purely literary factors. Jauß argues that their focus on the aesthetics of production and representation needs to be complemented by, indeed based on, the aesthetics of reception. ${ }^{23}$ Unlike traditional

\footnotetext{
${ }^{20}$ Hose (2016) this volume.

${ }^{21}$ Perkins (1992) 17.

22 Jauß (1970) 144-207. For an analysis of the approach to history in Jauß' Literaturgeschichte als Provokation, see Kablitz (2003) 91-101.

${ }^{23}$ Jauß (1970) 169: "Der geschlossene Kreis einer Produktions- und Darstellungsästhetik, in dem sich die Methodologie der Literaturwissenschaft bisher vornehmlich bewegt, muß daher auf eine Rezeptions- und
} 
literary history, Jauß zooms in on the "geschichtsbildende Energie" 24 inherent in the responses to literary works. It is only in the various acts of reception, both by readers and writers, that the meaning of a text comes to the light. The literary dimension of a text, not only its social and institutional aspects, is thus inextricably bound up with history, notably the responses it elicits.

It is not without logic that Jauß foregrounds reception and envisages its exploration as the basis of an inquiry into production and representation. After all, an aesthetics of reception permits the literary historian to trace the link between the work and his own interpretation. It is, as it were, a transcendental reflection on his own access to the text, which is mediated by earlier instances of reception. That being said, it has been duly noted that Literaturgeschichte als Provokation had little impact on the practice of writing literary histories. ${ }^{25}$ This is not surprising: an investigation of reception, even if there were sufficient evidence, would not yield a history of literature, but a history of the horizons of expectations. ${ }^{26}$ Engaging with previous responses to a text can prepare but not substitute its literary historical treatment. Jauß successfully demonstrates the entwinement of literature with history, but his Rezeptionsästhetik does not deliver the blueprint for literary history.

Two other points seem to be more pertinent to literary history than reception. Touched on fleetingly by Jauß, they are cast into relief by ancient literature. The first concerns literature's synchronic dimension. Besides harnessing reception as a key to a work's meaning, $\mathrm{Jau} ß$ also deems it necessary to reconstruct the contemporaneous horizon of expectations in which the work is presented. ${ }^{27}$ He first elaborates on the expectations resulting from the "preunderstanding of genres", "the form and topics of earlier works" and "the contrast between poetic and practical language", ${ }^{28}$ but later he also mentions non-literary, historical factors. ${ }^{29}$ In opposition to the Marxist project of a Widerspiegelungsästhetik, Jauß invokes the "geschichtsbildende Funktion der Literatur". ${ }^{30}$ Being not only at the receiving end, literature also influences history. The multi-faceted and reciprocal interaction between literature and history on which Jauß comments only in passing has more recently been put into the spotlight

\footnotetext{
Wirkungsästhetik geöffnet werden, wenn das Problem, wie geschichtliche Folge literarischer Werke als Zusammenhang der Literaturgeschichte zu begreifen sei, eine neue Lösung finden soll.“, 171: "Eine Erneuerung der Literaturgeschichte erfordert, die Vorurteile des historischen Objektivismus abzubauen und die traditionelle Produktions- und Darstellungsästhetik in einer Rezeptionsästhetik zu fundieren.“

${ }^{24} \mathrm{Jauß}(1970) 169$.

${ }^{25}$ Apel (2014) 54.

${ }^{26}$ Perkins (1992) 25 notes the structural complication.

${ }^{27} \mathrm{Jauß} \mathrm{(1970)} \mathrm{173-7.}$

${ }^{28} \mathrm{Jauß} \mathrm{(1970)} \mathrm{173-4.}$

${ }^{29}$ Jauß (1970) 199-207.

${ }^{30}$ Jauß (1970) 200.
} 
through the endeavours of New Historicism. ${ }^{31}$ Scholars such as Stephen Greenblatt not only erase the boundary between high-brow literature and mundane texts, they also emphasize the dialectic between (literary) text and (socio-political) context: texts circulate social energy and form part of negotiations. Instead of representing the world, literature helps to constitute reality.

Ancient literature lends itself to illustrating the claims of New Historicism. The archaic and classical performance culture in particular draws the attention to the social and political dimension of poetry. The symposium in which much monodic poetry was presented was an institution of aristocratic hetairiai. Elegy, iambic and lyric poetry were all part of the negotiation of the identity of the male elite in the ludic realm of strongly ritualized drinking parties. ${ }^{32}$ Attic tragedy is another case in point. The works of Aeschylus, Sophocles and Euripides were originally staged at a polis festival, alongside such rites as the honouring of benefactors of the city, the initiation of grown up war orphans as hoplites and the display of the tributes from the Delian league. ${ }^{33}$ The performative context underscores the political dimension of tragedy. But even later when literature had been established as a segment of cultural life defined more strongly through the relation of its own elements with each other than with other segments, a tight enmeshment of literature with politics can be observed. Just think of the authors of the Second Sophistic whose obsession with the classical past seems to have been not only an antiquarian pastime but also an attempt at defining Greek identity under Roman rule. ${ }^{34}$

The case of ancient Greece forcefully reminds us that literature is produced and received in specific contexts. Even in the modern era, which saw the emergence of literature as a seemingly independent and highly differentiated segment of cultural life, literature is by no means l'art pour l'art. In the terms of Bourdieu, the modern field of literature proliferates capital that is convertible and can thus be used in other fields. ${ }^{35}$ The regular visit to the municipal theater, to give an obvious example, helps cement a social place in the local bourgeoisie just as the attendance of avantgarde dance festivals may constitute a bohemian identity. Today's theatre is less ritualized than the performances in the Dionysus theatre in the $5^{\text {th }}$ century, and yet it is charged socio-politically, if in a different way and less emphatically. Ancient literature puts the spotlight on an aspect that is also present in modern literature.

\footnotetext{
${ }^{31}$ For an introduction, see Baßler (2001); Greenblatt (1984) has been particularly influential.

${ }^{32}$ E.g. Murray (1990); Vetta (1995).

${ }^{33}$ E.g. Goldhill (1987).

${ }^{34}$ E.g. Schmitz (1997), who explicitly draws on Bourdieu and New Historicism; Goldhill (2001).

${ }^{35}$ Bourdieu (1979).
} 
The second point that defines the historical nature of literature is its diachronic dimension. Jauß concentrates on the threads of reception and has little to say on the relation to previous texts, probably since this is the domain of traditional literary history. However, the recent and current assertions by post-structuralists and presentists make it necessary to emphasize that literature does not arise ex nihilo. Even the formalist credo, modeled on the self-fashioning of modern avantgarde authors, that literature develops in the mode of revolutionary innovation is predicated, if ex negativo, on the idea of tradition. The negation remains tied to the negated. And if we consider premodern literature, we encounter a notably different dynamics. ${ }^{36}$ Here tradition, the shaping influence of previous works, looms large. Its power is incarnated in Homeric epic whose reverberations can be heard across genres, in philosophy and historiography as well as in drama and lyric, with undiminished clarity from the Archaic to the Imperial period.

Beginning with the $5^{\text {th }}$ century, if not earlier, the notion of the new is present in ancient literature,${ }^{37}$ but on the whole it is based less on a radical rejection of tradition in the sense of the Russian formalists than on an artful play of variation. Across the ages, ancient Greek literature is engaged in a continuous agon at different levels. There is a competition within genres, for example when Euripides furnishes a version of the Orestes myth which is notably different from that given by his predecessors. ${ }^{38}$ Genres are also pitted against each other: whereas Herodotus and Thucydides present their accounts of the past as more credible than Homer's, Hellenistic poets cast their delicate formats as aesthetically more refined than previous poetry. The desire for aemulatio within and across genres weaves a tight intertextual net across through Greek literature. The rise of New Historicism has drawn our attention to the synchronic historicity of texts, and yet the case of ancient Greek literature is an important reminder that a full understanding of literature not only requires exploring its place in the contemporaneous discourse but also viewing it against the backdrop of previous works.

Certainly, literature speaks to us directly. It may be eventful in Gumbrecht's sense, immersing us in the represented world, and afford us an "encounter", as proclaimed by Wellbery. However, this "encounter" will be significantly richer if it is historically informed. For, as we have seen, literature itself is historical: it forms part of a socio-culturally constructed reality and relates in various ways to preceding works. Any understanding that leaves the synchronic and diachronic historicity of literature aside will be impoverished.

\footnotetext{
${ }^{36}$ Müller (2014) 168-9 on medieval literature.

${ }^{37}$ See, for example, Dunn (2007); d'Angour (2011).

${ }^{38}$ On the agonistic character of ancient literature, see, e.g., Griffiths ?
} 
In my eyes, the idea of literary history is not seriously affected by the postmodern credo that it is impossible to capture history fully in narrative. To start with, this claim is everything but original. Droysen, for one, noted in $1857:^{39}$

Immer aber, wie ergiebig auch die Forschung gewesen sein mag, die durch sie gewonnenen Vorstellungen decken sich bei weitem nicht mit der Fülle von Inhalt, Bewegung, Vielgestaltigkeit, realer Energie, welche die Dinge hatten, als sie Gegenwart waren. Und immer, welche Form auch für die Darstellung der gewonnenen Ergebisse der Forschung gewählt werden mag, diese Darstellung wird dem Sein der Dinge, wie es in ihrer Gegenwart und den damals Lebenden und Handelnden erschien, nur zum Teil, in gewisser Weise, nach gewissen Gesichtspunkten entsprechen können und wollen (darin kartographischen Darstellungen analog).

And before Droysen, already in the $18^{\text {th }}$ century, the Göttingen historian Chladenius identified the "Sehepunckt" as crucial for how the past is envisaged. ${ }^{40}$ In some regards, the case of literary history is distinct, but it certainly shares as a basic trait the perspectivity with general history. ${ }^{41}$

To go beyond this historical note, the fact that any literary history is necessarily perspectival does not mean that writing history literary is futile. It relativizes any claim to give the full picture, but it does not rule out the possibility of viewing literature historically. The decision to dispense with constructing lines of historical development because any narrative will ultimately fall short of the reality it tries to recount is, sad to say, deeply imbued with the naïve positivist representationalism it sets out to dethrone. Implicit is the assumption that an objective representation is the only worthy goal and that, if it is impossible to attain, the entire idea of a narrative needs to be discarded. However, just as the strict opposition of narrative versus experience is impossible to sustain, ${ }^{42}$ we have seen that literature itself is historical and thus needs to be viewed in historical terms. In fact, instead of shutting down literary history, the insight into its relativity rather inspires the production of literary histories. For any perspective taken, others are foreclosed that may also be worth pursuing and thus require other literary histories.

That being said, the acknowledgement of the perspectivity of literary history should make us reflect more on how to write it. In general, the challenge that perspectivity poses to enterprises which are presented as the history of ... seems to weigh in in favour of works that privilege an original approach over the desire for exhaustiveness. There cannot be a single authoritative history of literature; it is impossible and not required that a literary history

\footnotetext{
${ }^{39}$ Droysen (1977 [1857]) 445.

${ }^{40}$ Chladenius (1742) 189.

${ }^{41}$ Cf. Apel (2014) 56.

${ }^{42}$ Grethlein (2010) 319-24.
} 
covers all. What counts is the links that are constructed and the perspectives that are opened up. The format of A brief history of literature may not only be keyed to the exigencies of academic publishing today, it is, I think, also highly appropriate to the idea of literary history.

There are various choices the literary historian has to make. The very balance between synchronic and diachronic elements, for instance, can be calibrated differently. Both are important, but the selectivity of any narrative enforces a focus, which automatically means a neglect of other aspects. On the one hand, a strong interest in the literary dimension will favour the diachronic axis that shows the influences of earlier works. On the other, the attempt to capture the various entanglements of literature will shift the balance towards the synchronic. Here, the interactions of literature with politics compete with its resonances with other arts. Most choices of the literary historian ought to be considered not in terms of right or wrong, but of heuristic fruitfulness. The focus of literary history emerges in a constant interplay of the material to be investigated and the interest of the interpreter. Our understanding of archaic poetry, for example, has benefited greatly from the attention paid to its performative context, which is radically different from the modern place of literature. At the same time, after the wealth of synchronic studies in the last decades, it may be now worth inquiring into the diachronic dimension and thinking about the shaping influence of literary tradition. $^{43}$

The choice of a category that serves literary history as an organizing principle is pivotal. Most literary histories harness genre and author as their major organizing principles. As common as this rationale is, it is not without challenges. What, for example, do with Plutarch? Is it preferable to discuss his entire oeuvre together or to deal with the Lives under the heading of biography, then, in another chapter, to explore his philosophical treatises together with the works of other Imperial Platonists and finally to consider such works as $O n$ the Face of the Mood as part of Imperial science? Good reasons can be adduced for both strategies. While the former would shed light on the author Plutarch and the versatility of his writing, the later would enhance our understanding of the individual genres. Here as in other cases, there is not a single correct framework, but competing choices each of which simultaneously opens up and closes perspectives.

Martin Hose's Kleine griechische Literaturgeschichte illustrates that genre and author are not the only possible categories for the frame of literary history. It uses the forms and sites of production and circulation as a grid: "Aristokratische Festkultur" is followed by "klassische Stadtkultur", "hellenistische Herrscherhöfe” and "kaiserzeitliche Schulen”. This

\footnotetext{
${ }^{43}$ E.g. Swift (2010).
} 
structure draws our attention to the "Sitz im Leben", it highlights the social and political entanglements of ancient literature. Hose's focus on the context of production and reception pays off in particular for the performance culture of the archaic and classical eras in which texts tended to be firmly linked to specific socio-political contexts. It seems to be less powerful for the later eras in which literature, while still part of historical contexts, became defined more and more through literary aspects.

While literary histories can take different forms, there seem to be limits to the usefulness of the form of literary history. The Studies in Ancient Greek Narrative are a case in point. Irene de Jong and her collaborators adopt the form of literary history to explore narratological categories. The three volumes published so far investigate the notions of narrators, narrative time and narrative space in chapters devoted to individual author who are chronologically arranged and subsumed under genres. Is there any gain, I wonder, in having a historical account of narratological categories? The result does not justify the project: neither a link between the categories and genre nor a historical development can be observed. As de Jong notes in the conclusion of the first volume, there is "no direct correlation between genre and type of narrator" 44 and "the first texts we have, the Homeric epics display much of the narratorial repertoire and handle it in virtuouso manner". 45

The diachronic analysis of narrative is a fascinating field and, due to the ahistorical premises of narratology, still in its infancy. However, the Studies in Ancient Greek Narrative illustrate that the schematic investigation of narratological categories in the format of literary history does not serve the purposes of historical narratology. On the contrary, the ambition to demonstrate that Homer features all narrative devices "which modern narratology has identified" 46 rather stymies efforts to tease out the differences between ancient and modern narrative. A historical understanding of narrative requires a more nuanced approach that offers an in-depth analysis of select texts, considers various narrative categories together and takes into account the medial and performative background. The main narratological categories can be immensely useful for a better understanding of individual works; their historical parsing, however, easily becomes tedious.

\section{Synopsis}

\footnotetext{
${ }^{44}$ De Jong (2004) 545.

${ }^{45}$ De Jong (2004) 552.

${ }^{46}$ De Jong (2007) 36.
} 
By no means does this volume aspire to treat the topic of Greek literary history exhaustively. Its aim is far more modest, namely to identify literary history as something that is not only used by Classicists more or less on a daily basis, but that deserves some reflection. Whereas scholars in other fields have discussed the issues and pitfalls of literary history, Classicists, apart from very few noteworthy exceptions, have not engaged in such a debate. The salience of literary histories as an auxiliary seems to have kept us from giving much thought to them and is simultaneously the reason why we ought to inquire into their forms and functions, capacities and limits. In order to establish Greek literary history as a topic on the agenda of Classicists, this volume combines various perspectives that can be divided into two strands. While the first half of essays considers the modern practice of Greek literary history, examining its intellectual premises and key concepts such as genre and epoch, the second half is concerned with the beginnings and traces of literary history in antiquity. A brief synopsis of the individual papers will help the reader to orientate himself.

As I noted, modern literary history is deeply imbued with central tenets of Historicism. Not least the idea of development and a keen sense for the gap separating the past from the present are essential to most traditional literary histories. Tim Whitmarsh probes into some of the central issues of Historicism and their impact on literary history. Most incisively, the hermeneutic circle manifests its power through the question of how to relate texts and contexts. Whitmarsh's test-cases are the ideology of Augustean poetry, whether it ought to be understood as optimist or pessimist, the political interpretation of Greek tragedy and the possibility of alternative approaches, and the implications that the use of Second Sophistic as an epoch has for our understanding of Imperial texts. As Whitmarsh finally shows, some of the tensions pervading Historicism are exacerbated in the case of literature which is part of a context and yet lays claim to universal meaning.

Martin Hose considers some of the problems that modern literary theory creates for the practice of literary history in general and Greek literary history in particular. Notably the death of the author seems to pose a challenge, as the author used to be a central category for writing literary history. In Hose's eyes, the case of Greek literature aggravates the problem: There is too little information available to use for the causal relations that Hose deems pivotal to literary history. Not even for Euripides do we have sufficient data to explain causally why he wrote, say, the Iphigenia in Aulis. Hose thus makes the radical proposal to abandon the author as a central category of literary history. Instead, he argues, one should concentrate on what he labels 'Ermöglichungszusammenhänge der Literatur', besides the producers and 
recipients essentially the media and the institutional background and the impact that they have on the forms of literature.

Günter Figal establishes a dialogue between philosophy and literature that elucidates the capacities and boundaries of literary history. He shows how in the Sophistes Plato, while distinguishing philosophy from literature, uses the form of literature to gesture towards the truths of philosophy. Hegel then removes philosophy from the realm of literature, envisaging it as the final step in the movement of the spirit. Against this, Nietzsche, harking back to Plato, insists on the literary nature of philosophy. As different as these three philosophical approaches are, they are all, as Figal shows, somehow predicated on a literary history of philosophy. Literary history, Figal continues to argue, builds on an underlying dynamic between the Wirkungsgeschichte, that is the power of a text as it unfolds in history, and the history of its reception. Just as philosophy cannot overcome history, literature cannot be confined to its historical aspects: both belong to the realm of hermeneutics.

Epochs are a crucial category of literary history. Antonios Rengakos discusses the example of the Hellenistic Age. He traces its development as a central epoch in literary histories, how it was first coined as a historical epoch by Droysen and then transferred to literary history. After discussing early histories of Hellenistic literature, Rengakos surveys more recent attempts. He shows the impact that other histories, art histories and cultural histories, have on our idea of Hellenistic literature and defends the value of contextualizing texts.

Two papers tackle another crucial category of literary history besides author and epoch, namely genre. Tilg's essay is devoted to the novel, a genre 'without name, theory and fixed form', as stated in the subtitle. The novel, it seems, lacked prestige and came too late to become the object of critical discussions in antiquity. The five fully preserved ancient Greek novels all qualify as romance, but this should not lead us to identify the ancient novel with romance. Tilg alerts us to great variety of ancient novels that included travel novels, picaresque novels and the ass novels as well as the love novel. He proposes the broad definition of 'a longer fictional narrative in prose' under the umbrella of which various kinds of novels, just as in the modern era, have place. For Tilg, the novel is ultimately a 'Naturform der Weltliteratur' that can be found across literary traditions.

Focusing on Latin love elegy, Kofler assesses the impact that Greek literary history has had on histories of Latin literature. Latin love elegy may seem to be a clear-cut genre, but under Kofler's critical scrutiny straightforward definitions turn out to be problematical. Kofler's exemplary discussion reveals the benefits and issues inherent in the systematizing on 
which literary histories are predicated. Continuing his argument, Kofler proposes that the too rigid definitions are ultimately owed to elegy's slave-like relation with Greek literary history. For a long time, the history of Latin literature was mainly seen as the process of adopting Greek models. Even when Latin literature was considered in its own right, Hellenocentrism did not loosen its grip: now scholars paid particular attention to genres that seemed to be without strong Greek predecessors. Latin love was seen as a strong candidate for a genuinely Roman genre and thus, Kofler argues, given a too rigid definition.

It is widely agreed that the kind of literary history which emerged in the $18^{\text {th }}$ and $19^{\text {th }}$ centuries was not practiced in antiquity. Such treatises as Aristotle's Peri poieton and Peri philosophias, Theophrast's Physikon doxia, Callimachus' Pinakes, Dionysius' On old rhetors and Diogenes Laertius' History of philosophy would not qualify as literary history. ${ }^{47}$ And yet, as Halliwell puts it poignantly in this volume, denying antiquity a sense of literary history would be not unlike asserting that there were no historians before the $19^{\text {th }}$ century. The essays assembled in the second half of the volume therefore trace the idea of literary history in antiquity. Besides papers discussing ancient texts that, while not literary histories in our sense, are devoted to the history of literature there are others that tackle notions of literary history encapsulated in other texts. By no means are Aristophanes' Frogs or Plato's Timaeus literary history, and yet, they reflect an understanding of literature as historical which needs to be taken into account if we wish to capture the ancient origins of literary history. What is more, as the case of the Frogs nicely illustrates, their implicit constructions of the history of literature have often influenced the lines drawn in our literary histories.

Laemmle's paper, for instance, demonstrates that canonization is at the core of literary histories, but also takes place in literature. She uses the reception of tragedy to show that in both antiquity and the Modern era the canon was the object of reflections and witty play. In addition to the Frogs, Laemmle discusses an epigram on Astydamas and Lucian's How to Write History to tease out some of the subtleties involved in the emergence of Aeschylus, Sophocles and Euripides as the classical triad of tragedy. Then she turns to $18^{\text {th }}$ century Germany and shows Wieland's engagement with the canonization of the three tragedians. In evoking the reception of Euripides in Geschichte der Abderiten, Wieland slyly fashions himself as Euripides redivivus while casting Goethe, who had disparaged his play Alceste, as

${ }^{47}$ E.g. Fuhrmann 1983. On treatises that are somehow literary historical approaches in the Peripatetic tradition and in Hellenism, see, for example, Blum 1977. 
his Aristophanes. The ancient canonization has become the fuel in the modern race for the prime places in the canon.

In his broad survey, Montanari focuses on literary history understood in a strict sense as implying a notion of literature, the idea of historical development and an engagement with an author's biography. He starts with Aristotle, who occupies a key position in this trajectory and then assembles what we know about earlier authors and their interest in literary history. It seems that Homer and the poems of the Trojan cycle gave rise to questions about authorship that occupied such writers as Theagenes of Rhegium and Hellanicus of Lesbos. The idea of genealogies and relations between masters and pupils were pivotal to comprehending the development of literature. In a final part, Montanari looks beyond Aristotle discussing the Peripatetic tradition and Alexandrian scholarship which systematized the study of literature to an extent hitherto unknown.

Plato did not write literary history, and yet Michael Erler shows how he implicitly locates the form of his writing, the dialogue, in the literary tradition. He first suggests that Eustathius' anecdote about Plato burning his poetic works was developed from an anecdote that can be found in the Timaeus: There an old man reports that Solon did not finish his poetic work in Egypt, otherwise he would have surpassed Homer. Erler then takes a close look at the context of this passage in the Timaeus. He argues that the reference to Solon's attempt to write a poem on the conflict between old Athens and Atlantis and the account of this quarrel then given by Critias evoke the genre of encomium as a foil to Plato's work. Plato seems to signal that his dialogues transform the idea of the encomium, substituting praise with 'therapeutic punishment'. As Erler's argument shows, Plato's dialogue are not only carefully crafted literature, they are also stylized with an acute awareness of literary history.

\section{Montanari}

Aristotle was a central figure for the writing of literary history in antiquity. Unfortunately, his works on the lives of poets as well as his lists of didaskaliai have not been preserved nor do we have much more than the titles of similar works by his Peripatetic followers. At the same time, chapters 4 and 5 of the Poetics contain the nucleus of a literary history which Halliwell juxtaposes with the comments on historiography in chapters 9 and 23. There is an obvious tension between the teleological account of the history of literature that is neglectful of particulars and the claim that historiography is concerned more with particulars than universals, but, as Halliwell shows with characteristic diligence, this tension is more complex than it may seem. While the naturalism of chapters 4 and 5 does not imply a straightforward biological model, chapters 9 and 23 do not reduce historiography to 
chronicles. Furthermore, in other works Aristotle seems to grant universals to history. The tension that nonetheless remains prefigures some of the issues with which modern literary history has been grappling.

Kim

Literary history can be encapsulated in the self-fashioning of an author through intertextuality. This may be nowhere more obvious than in an epoch as self-conscious and infatuated with the classical past as the Imperial era. In his paper, Richard Hunter scrutinizes Dio's Oration 13. Dio's account of his exile may be of doubtful value as a source for his biography, but it shows him in full swing developing his authorial persona against the backdrop of earlier authors. An engagement with Homer, Plato, Xenophon and, possibly, Antisthenes helps Dio to locate himself between philosophy and rhetoric, a powerful legacy of Plato in antiquity and, as Figal's argument illustrates, beyond. Hunter traces an arc that reaches from the first, the 'Socratic' speech to the second, the 'Roman' speech in Oration 13, mimicking the standard progression of elite education: While the first speech is introduced as his memory of a speech by Socrates, the second is presented as an imitation, perhaps dramatizing the adaptation of Greek culture in a Roman context. Literary history is here the stuff out of which autobiography is made.

Recent scholarship has identified the scholia as an intriguing form of ancient criticism beyond the standard poetics. Scholia are also an important source for ancient attitudes towards literary history. Athanassios Vergados explores the comments on Hesiod in the Homeric scholia to show that the scholia are predicated on literary historical ideas, in fact refer to literary history in their arguments. The scholia on Homer often reference Hesiod to derive parallels for linguistic or material phenomena. While this implies a sense of closeness, other scholia express the assumption that Hesiod was younger and reflects new developments that were still unknown to Homer. Some of these scholia envisage Hesiod as a keen reader of Homer when they identify mistakes as misunderstandings of Homer. Strikingly, they criticize him in the same terms as other critics, thus giving the impression that Hesiod was a critic himself or that they themselves belong to literary history.

- Engaging with ancient literary history in wide sense for modern literary history premised on it: archaic lyric poetry: Perkins 1992: 69-70. 
Synopsis

\section{Bibliographie}

Apel (2014): Friedmar Apel, “Belebung und Organisazion sind die Grundsätze ächt historischer Kunstgebilde'. Rückblickende Überlegungen $\mathrm{zu}$ einer narrativen Erneuerung der Literaturgeschichte aus dem Geiste des 93. Blüthenstaubfragments des Novalis“, in: Matthias Buschmeier, Walter Erhart and Matthias Kaufmann (eds.), Literaturgeschichte. Theorien - Modelle - Praktiken (Studien und Texte zur Sozialgeschichte der Literatur 138), Berlin, 49-62.

Bakker (2002): Egbert J. Bakker (ed.), Brill's Companion to Herodotus, Leiden.

Baßler (2001): Moritz Baßler (ed.), New Historicism. Literaturgeschichte als Poetik der Kultur, Tübingen.

Benjamin (1991 [1912-1931]): Walter Benjamin, Gesammelte Schriften III. Kritiken und Rezensionen 1912-1931, ed. Hella Tiedemann-Bartels, Berlin.

Blum, R. (1977): Rudolf Blum, Kallimachos und die Literaturvergleichung bei den Griechen. Frankfurt.

Bourdieu (1997): Pierre Bourdieu, La Distinction. Critique Sociale du Jugement, Paris.

Buschmeier (2014): Matthias Buschmeier, "Pragmatische Literaturgeschichte. Ein Plädoyer", in: Matthias Buschmeier, Walter Erhart and Matthias Kaufmann (eds.), Literaturgeschichte. Theorien - Modelle - Praktiken (Studien und Texte zur Sozialgeschichte der Literatur 138), Berlin, 11-29.

Chladenius (1742): Johann Martin Chladenius, Einleitung zur richtigen Auslegung vernünftiger Reden und Schriften, Leipzig (reprint Düsseldorf 1969).

Croce (1918): Benedetto Croce, "La Riforma della Storia Letteraria ed Artistica“, in: La Critica $16,1-16$.

d'Angour (2011): Armand d'Angour, The Greeks and the New. Novelty in Ancient Greek Imagination and Experience, Cambridge.

de Jong (2004): Irene J. F. de Jong, Narrators and Focalizers. The Presentation of the Story in the Iliad, London.

de Jong (2007) : Irene J. F. de Jong, "Homer", in: Irene J. F. de Jong and René Nünlist (eds.), Time in Ancient Greek Literature. Studies in Ancient Greek Narrative II (Mnemosyne 291), Leiden, 21-38.

de Man (1971): Paul de Man, "Literary history and literary modernity", in: Paul de Man, Blindness and Insight. Essays in the Rhetoric of Contemporary Criticism, New York, $142-65$.

Dewald (2006): Carolyn Dewald (ed.), The Cambridge Companion to Herodotus, Cambridge.

Droysen (1977 [1857]): Johann Gustav Droysen, Historik (Bd. 1). Rekonstruktion der ersten vollständigen Fassung der Vorlesungen (1857), eds. Peter Leyh and Horst Walter Blanke, Stuttgart/Bad Cannstatt.

Dunn (2007): Francis M. Dunn, Present Shock in Late Fifth-Century Greece, Ann Arbor (MI).

Elliott (1988): Emory Elliott (general ed.), Columbia Literary History of the United States, New York.

Fuhrmann (1983): Manfred Fuhrmann "Die Geschichte der Literaturgeschichtsschreibung von den Anfängen bis zum 19. Jahrhundert", in: Bernard Cerquiglini und Hans Ulrich Gumbrecht (eds.), Der Diskurs der Literatur- und Sprachhistorie, Frankfurt, 49-72.

Goldhill (1987): Simon Goldhill, “The Great Dionysia and Civic Ideology”, JHS 107, 58-76.

Goldhill (2001): Simon Goldhill (ed.), Being Greek under Rome. Cultural Identity, the Second Sophistic and the Development of Empire, Cambridge. 
Greenblatt (1984): Stephen Greenblatt, Renaissance Self-Fashioning. From More to Shakespeare, Chicago.

Grethlein (2010): Jonas Grethlein, "Experientiality and Narrative Reference. With Thanks to Thucydides", in: History and Theory 49, 315-35.

Gumbrecht (2008): Hans Ulrich Gumbrecht, "Shall We Continue to Write Histories of Literature?", in: New Literary History 39/3, 519-32.

Hamacher (1986): Werner Hamacher, "Über einige Unterschiede zwischen der Geschichte literarischer und der Geschichte phänomenaler Ereignisse", in: Wilhelm Voßkamp and Eberhard Lämmert (eds.), Historische und aktuelle Konzepte der Literaturgeschichtsschreibung - Zwei Königskinder? Zum Verhältnis von Literatur und Literaturwissenschaft (Akten des VII. internationalen Germanisten-Kongresses Göttingen 1985, vol. II), Tübingen, 5-15.

Hose (1999) Martin Hose, Kleine griechische Literaturgeschichte, München.

Jauß (1970): Hans Robert Jauß, Literaturgeschichte als Provokation, Frankfurt am Main.

Kablitz (2003): Andreas Kablitz, "Literaturwissenschaft als Provokation der Literaturgeschichte. Überlegungen zum Konzept des 'Historischen' in der Literaturgeschichte des 19. Jahrhunderts (am Beispiel von Victor Hugos Préface de Cromwell und Francesco de Sanctis' Storia della letteratura italiana)“, in: Poetica 35, 91-122.

Marincola (2011): John Marincola (ed.), A Companion to Greek and Roman Historiography, Malden (MA).

Most (2008): Glenn W. Most, "What was literary history?", in: Jürg Berthold and Boris Previšić (eds.), Texttreue. Komparatistische Studien zu einem masslosen Massstab (Variations 9), Bern, 195-207.

Müller (2014): Jan-Dirk Müller, "Literaturgeschichtsschreibung als Mikrogeschichte. Zur Schwierigkeit, eine Geschichte vormoderner Literatur $\mathrm{zu}$ schreiben“, in: Matthias Buschmeier, Walter Erhart and Matthias Kaufmann (eds.), Literaturgeschichte. Theorien - Modelle - Praktiken (Studien und Texte zur Sozialgeschichte der Literatur 138), Berlin, 165-84.

Murray (1990): Oswyn Murray, Sympotica. A Symposium on the Symposion, Oxford.

Oexle (1996): Otto Gerhard Oexle, "Meineckes Historismus. Über Kontext und Folgen einer Definition", in: Otto Gerhard Oexle and Jörn Rüsen (eds.), Historismus in den Kulturwissenschaften, Köln, 139-99.

Perkins (1992): David Perkins, Is Literary History Possible?, Baltimore.

Pitcher (2009): Luke Pitcher, Writing Ancient History. An Introduction to Classical Historiography, London.

Rengakos (2006): Antonios Rengakos (ed.), Brill's Companion to Thucydides, Leiden.

Schmitz (1997): Thomas Schmitz, Bildung und Macht. Zur sozialen und politischen Funktion der zweiten Sophistik in der griechischen Welt der Kaiserzeit (Zetemata 97), München.

Swift (2010): Laura Swift, The Hidden Chorus. Echoes of Genre in Tragic Lyric, Oxford.

Vetta (1995): Massimo Vetta (ed.), Poesia e Simposio nella Grecia Antica. Guida Storica e Critica, Bari.

Wellbery (2004): David E. Wellbery (ed.), A New History of German Literature, Cambridge (MA).

Wellek (1956): René Wellek, "The concept of evolution in literary history", in: Morris Halle et al. (eds.), For Roman Jakobson. Essays on the Occasion of His Sixtieth Birthday, The Hague, 653-61.

Wellek (1973): René Wellek, “The fall of literary history”, in: Reinhard Koselleck and WolfDieter Stempel (eds.), Geschichte - Ereignis und Erzählung (= Poetik und Hermeneutik 5), München, 427-40.

Wellek/Warren (1949): René Wellek and Austin Warren, Theory of Literature, New York. 
Whitmarsh (2004): Tim Whitmarsh, Ancient Greek Literature, Cambridge.

Zimmermann (2011): Bernhard Zimmermann (ed.), Handbuch der griechischen Literatur der Antike (2 vols.), München. 